\title{
Plasma zinc and its relationship to clinical symptoms and drug treatment in rheumatoid arthritis
}

\author{
ZSOLT BALOGH, ${ }^{1}$ AHMED F. EL-GHOBAREY, ${ }^{1}$ GORDON S. FELL, ${ }^{2}$ \\ D. H. BROWN, ${ }^{3}$ J. DUNLOP, ${ }^{3}$ AND W. C. DICK ${ }^{1}$
}

From the ${ }^{1}$ Centre for Rheumatic Diseases, and University Department of Medicine, and ${ }^{2}$ University Department of Biochemistry, Glasgow University, and the ${ }^{3}$ Department of Pure and Applied Chemistry, University of Strathclyde, Glasgow

SUMMARY Total plasma zinc levels in patients with rheumatoid arthritis on different therapeutic treatments were determined in conjunction with total serum proteins, serum albumin and globulin, and articular index of joint tenderness, erythrocyte sedimentation rate, rheumatoid factor, serum copper, and serum iron. There were significantly lower zinc levels in patients with rheumatoid arthritis on nonsteroidal anti-inflammatory drugs than in patients on levamisole and penicillamine. Zinc levels correlated positively with serum albumin, and there was an inverse correlation between zinc levels and both ESR and globulin concentration in all rheumatoid patients. However, the correlation coefficient varied in the different treatment groups. The results of this study support the hypothesis that low plasma zinc level in rheumatoid arthritis is one of the nonspecific features of inflammation.

Strangely, considerably less attention has been paid to divalent as opposed to monovalent cation metabolism in medicine. This may be attributable to the earlier appearance of simple methods of measurement for the alkali metals $\left(\mathrm{Na}^{+}, \mathrm{K}^{+}\right)$rather than to their relative biological importance. Elevation of serum copper and ceruloplasmin has long been associated with rheumatoid arthritis, and we have recently reported a relationship between serum copper, serum iron, articular index of joint tenderness, and erythrocyte sedimentation rate. ${ }^{1}$

Zinc is intimately involved in numerous biological systems of relevance to patients with arthritis ranging over collagen and bone metabolism, ${ }^{2,3}$ complement system, ${ }^{4}$ lysosomal enzyme release, ${ }^{5}$ and macrophage functions. ${ }^{6}$ Zinc deficiency in chickens is associated with an arthropathy, ${ }^{7}$ and in man alteration of zinc metabolism may be associated with wound healing, ${ }^{8}$ cutaneous ulceration, ${ }^{9}$ severe burns, ${ }^{10}$ liver disease, ${ }^{11}$ and hypogonadal dwarfism. ${ }^{12,13}$ Drug treatment, particularly with corticosteroid drugs ${ }^{14}$ or penicillamine, ${ }^{15}$ may influence zinc levels, and it has been reported that administration of zinc sulphate improves the clinical status of patients with rheumatoid arthritis. ${ }^{16}$

Accepted for publication 29 June 1979.

Correspondence to Dr Z. Balogh, H-1021 Budapest, Tarogato ut 112, Hungary.
Zinc in plasma is mainly bound to proteins, both albumin (about 60\%) and globulins ( $\alpha 2$ macroglobulin about $35 \%$ ), and the biologically active fraction is partly complexed to amino acids, in particular histidine (about 5\%). ${ }^{17,18}$ Histidine concentrations are low in patients with rheumatoid arthritis, ${ }^{19}$ but plasma zinc has been variously reported to be raised, ${ }^{20}$ normal, ${ }^{21,22}$ or depressed, ${ }^{3,23}$ possibly due to differences in the patients studied and to differences in treatment. ${ }^{1,24}$ We have reported a reduction in plasma zinc in some patients with rheumatoid arthritis and have pointed out that total body zinc is not accurately reflected by measurements of plasma zinc, ${ }^{25}$ since, like potassium ${ }^{26}$ zinc exists mainly in the intracellular compartment.

In the present study we have focused attention on different drug treatments and their effect on total plasma zinc, and we have also examined some inter-relationships between zinc and rheumatoid factor, clinical indices of activity, various plasma proteins, and other divalent cations.

\section{Materials and methods}

One hundred and forty patients (mean age $54 \cdot 1$ years, \pm SEM 4.9 years), of whom 45 were males, were studied. All the patients had classical or definite rheumatoid arthritis ${ }^{27}$ with a mean disease duration 
of 8.6 years ( \pm SEM 0.9 years). All patients had radiological evidence of articular erosions, and in 104 patients serological tests for IgM rheumatoid factor were positive. The mean articular index of joint tenderness ${ }^{24}$ was 11.4 score points $( \pm$ SEM $1 \cdot 7)$ and ESR in the first hour $26.7 \mathrm{~mm} \pm$ (SEM 2.7). Seventy-three patients were treated with levamisole, 15 patients with penicillamine, and the other 52 were receiving a number of nonsteroidal anti-inflammatory drugs (NSAI). None of these patients were receiving corticosteroid drugs, and no patient had clinical signs of any of the seronegative spondylarthritides.

In all the patients plasma zinc was estimated by atomic absorption spectrophotometry, ${ }^{28}$ care being taken to avoid contamination of specimens by the use of appropriate syringes, needles, and specimen tubes. The blood from all patients was withdrawn after breakfast at the same time of the day, between 9 and 12 a.m. Rheumatoid factor was measured by the R3 titration test. ${ }^{29}$ Total serum copper was estimated by atomic absorption spectrophotometry with carbon furnace atomisation, ${ }^{30}$ again with considerable care being taken to avoid contamination.

\section{Results}

The mean plasma zinc concentration in all patients studied was $11 \cdot 74 \pm$ SEM $0 \cdot 21 \mu \mathrm{mol} / 1$, which was significantly lower than that of the normal values (mean: $15 \cdot 1 \pm$ SEM $0 \cdot 17 \mu \mathrm{mol} / 1=99 \pm$ SEM $11 \mu \mathrm{g} / 100 \mathrm{cc}$ ) taken from 100 subjects obtained in this laboratory. ${ }^{28}$

Table 1 Plasma zinc values in different treatment groups of patients with rheumatoid arthritis

\begin{tabular}{lll}
\hline Treatment & $\begin{array}{l}\text { Number of } \\
\text { patients }\end{array}$ & $\begin{array}{l}\text { Plasma zinc in } \\
\mu \text { mol } / l(\text { mean } \pm S E M)\end{array}$ \\
\hline Levamisole & 73 & $12 \cdot 62 \pm 0 \cdot 277$ \\
Penicillamine & 15 & $11 \cdot 86 \pm 0 \cdot 674$ \\
NSAI & 52 & $10 \cdot 47 \pm 0 \cdot 282$ \\
Total & 140 & $11 \cdot 74 \pm 0 \cdot 209$ \\
\hline
\end{tabular}

Significance: Levamisole-NSAI, $t=5 \cdot 28, P<0 \cdot 001$. PenicillamineNSAI, $t=2 \cdot 17, \mathrm{P}<0 \cdot 05$. Levamisole-penicillamine, $t=1 \cdot 10, \mathrm{P}$ not significant.
Patients treated with NSAI drugs had a mean plasma zinc concentration $(\mu, 10 \cdot 47 \pm$ SEM 0.28 $\mu \mathrm{mol} / \mathrm{l})$, which was significantly lower than were the results obtained in patients treated with levamisole $(\mu, 12.62 \pm$ SEM $0.28 \mu \mathrm{mol} / 1, \mathbf{P}<0.001)$ or with penicillamine $(\mu, \quad 11.86 \pm$ SEM $0.67 \mu \mathrm{mol} / 1$, $P<0 \cdot 05)$. There was no significant difference between the results with levamisole and penicillamine (Table 1).

The results for ESR in the patients receiving NSAI drugs $(\mu, 40 \cdot 1 \pm \operatorname{SEM~} 7 \cdot 2 \mathrm{~mm} / \mathrm{h})$ were significantly higher than those obtained in patients receiving levamisole $(\mu, 21 \cdot 8 \pm$ SEM $2.9 \mathrm{~mm} / \mathrm{h}$; $t=2 \cdot 81, \mathrm{P}<0 \cdot 01)$, but there was no significant difference between the results obtained with penicillamine $(\mu, 29.0 \pm$ SEM $7.9 \mathrm{~mm} / \mathrm{h})$ and either the results with NSAI drugs $(t=1 \cdot 01$, NS) or those with levamisole $(t=0.99$, NS).

There were a significant inverse correlation between plasma zinc concentration and the ESR in all patients studied $(\mathrm{r}=-0.448, \mathrm{P}<0.001)$ and in the patients treated with levamisole $(r=-0.406$, $\mathrm{P}<0.01$ ), but no significant correlation in the patients receiving either NSAI drugs or penicillamine (Table 2).

The plasma zinc concentration in those patients with an ESR of less than $50 \mathrm{~mm} / \mathrm{h}(\mu, 12 \cdot 12 \pm$ SEM $0.26 \mu \mathrm{mol} / \mathrm{l})$ differed significantly $(t=4 \cdot 59$, $P<0.001)$ from the result in those patients with an ESR in excess of $51 \mathrm{~mm} / \mathrm{h}(\mu, 9.46 \pm$ SEM 0.52 $\mu \mathrm{mol} / \mathrm{l})$.

There was a significant correlation between plasma zinc concentration and serum albumin in the total group $(r=0.419, P<0.001)$ in the patients treated with levamisole $(r=0.414, P<0.02)$ and in the patients receiving penicillamine $(\mathrm{r}=0.817, \mathrm{P}<0.02)$, but no significant correlation in those receiving NSAI drugs. There was a significant inverse correlation between plasma zinc and serum globulin concentrations in the total group $(r=-0 \cdot 305$, $P<0.01)$ and in those treated with NSAI drugs $(r=-0.427, P<0.05)$, but no significant correlation in the other treatment groups (Table 2).

No significant relationship was recorded between total serum protein concentration, rheumatoid

Table 2 Correlation between plasma zinc values and ESR, serum albumin, and serum globulin in different treatment groups of patients with rheumatoid arthritis

\begin{tabular}{|c|c|c|c|c|c|c|c|c|c|c|c|c|}
\hline & \multicolumn{12}{|c|}{ Treatment groups } \\
\hline & \multicolumn{3}{|c|}{ Levamisole } & \multicolumn{3}{|c|}{ Penicillamine } & \multicolumn{3}{|c|}{ NSAI } & \multicolumn{3}{|c|}{ Total } \\
\hline & No. & $r$ & $\boldsymbol{P}$ & No. & $r$ & $P$ & No. & $r$ & $\boldsymbol{P}$ & No. & $r$ & $\boldsymbol{P}$ \\
\hline $\begin{array}{l}\text { ESR } \\
\text { Albumin } \\
\text { Globulin }\end{array}$ & $\begin{array}{l}50 \\
37 \\
37\end{array}$ & $\begin{array}{r}-0.406 \\
0.414 \\
-0.175\end{array}$ & $\begin{array}{l}0.01 \\
0.02 \\
\text { NS }\end{array}$ & $\begin{array}{r}11 \\
8 \\
8\end{array}$ & $\begin{array}{r}-0.536 \\
0.817 \\
-0.534\end{array}$ & $\begin{array}{l}\text { NS } \\
0.02 \\
\text { NS }\end{array}$ & $\begin{array}{l}17 \\
25 \\
25\end{array}$ & $\begin{array}{r}-0.440 \\
0.112 \\
-0.427\end{array}$ & $\begin{array}{l}\text { NS } \\
\text { NS } \\
0.05\end{array}$ & $\begin{array}{l}78 \\
70 \\
70\end{array}$ & $\begin{array}{r}-0.448 \\
0.419 \\
-0.305\end{array}$ & $\begin{array}{l}0.001 \\
0.001 \\
0.01\end{array}$ \\
\hline
\end{tabular}


factor titre, serum copper or iron concentration, or articular index of joint tenderness and plasma zinc concentration.

\section{Discussion}

Early literature on this subject was bedevilled by methodological problems which could go some way towards explaining the apparent discrepancies. ${ }^{20,22,23,31}$ The results of this study confirm and extend our previous observation ${ }^{3}$ that the plasma zinc concentration in patients with rheumatoid arthritis receiving NSAI drugs is low. In that study we looked at patients receiving NSAI drugs and corticosteroids. In the present study we have compared the former group with patients receiving 'second line' antirheumatic drugs ${ }^{32}$ such as penicillamine and levamisole. It has been suggested that such regimens may alter the rate of progression of the underlying disease, ${ }^{33,34}$ and this effect may be reflected in reduction in acute-phase protein concentrations and ESR. ${ }^{35}$ Certainly in the present study plasma zinc concentrations, ESR, and globulin concentrations were lower in those patients receiving levamisole, and serum albumin concentrations were higher. The results for patients receiving penicillamine were intermediate. In particular the results in all patients for plasma zinc concentrations were lower in those subjects with the highest ESRs'

We have demonstrated a significant relationship between the ESR and plasma zinc concentrations, and the inter-relationships extend in much the direction one would expect, since low plasma zinc concentrations are also related to high globulin and low albumin concentrations. It is relevant in this context that, although $\alpha 2$ macroglobulin is particularly associated with plasma zinc, as much as $60 \%$ of zinc is bound to albumin and a small but highly significant amount to amino acids, especially histidine. ${ }^{36,} 37$ It is interesting that plasma zinc concentrations were significantly related to serum albumin but not globulin concentrations in those patients receiving second line drugs (penicillamine and levamisole) but not in those patients receiving NSAI drugs. On the other hand plasma zinc concentrations were significantly related to serum globulin concentrations only in those patients receiving NSAI drugs.

It is possible that changes in plasma zinc in chronic inflammatory diseases may reflect changes in leucocyte endogenous mediator (LEM). It is suggested that this is released from polymorphonuclear leucocytes during phagocytosis as a result of a wide variety of nonspecific stimuli. ${ }^{38}$ LEM subsequently exerts an effect on the hepatocyte which results in enhanced uptake of amino acids such as histidine, which are thereafter used as the building blocks for acute phase proteins. Zinc both independently and in association with histidine is thus concentrated from plasma into the hepatocyte, with consequent reduction in plasma concentration. ${ }^{39-41}$ This may account for the reduction in plasma but not in total body zinc concentrations in patients receiving NSAI drugs for rheumatoid arthritis. The subsequent increase in synthesis of acute phase proteins may explain the elevation of plasma ceruloplasmin and kininogen ${ }^{39,42}$ and through this the elevated copper concentrations in rheumatoid arthritis. Second line drugs such as gold, penicillamine, or levamisole produce the reverse effect whether primarily or through intermediate mechanisms. If this is correct, then it seems likely that most of these phenomena are entirely nonspecific and may not be common to other chronic inflammatory diseases. Furthermore, if this is correct, such interrelated biochemical mechanisms are probably in dynamic equilibrium, and results obtained at any single time must be interpreted in perspective.

\section{References}

1 Brown D H, Buchanan W W, El-Ghobarey A F, Smith W E, Teape J. Serum copper and its relationship to clinical symptoms in rheumatoid arthritis. Ann Rheum Dis 1979 ; 38; 174-176.

2 Fernandez-Madrid F, Prasad A S, Oberleas D. Effect of zinc deficiency on collagen metabolism. J Lab Clin Med $1971 ; 78 ; 853-853$.

3 Kennedy A C, Fell G S, Stevens W H, Dick W C, Buchanan W W. Zinc: its relationship to osteoporosis in rheumatoid arthritis. Scand J Rheumatol 1975; 4; 243-245.

4 Yamamoto K, Takahashi H. (1975). Inhibition of the terminal stage of complement-mediated lysis (reactive lysis) by zinc and copper ions. Int Arch Allergy Appl Immunol 1975; 48; 653-663.

5 Chvapil M, Ryan J N, Zukoski C F. (1972). The effect of zinc and other metals on the stability of lysosomes. Proc Soc Exp Biol Med 1972; 140; 642-646.

6 Karl L, Chvapil M, Zukoski C F. Effect of zinc on the viability and phagocytic capacity of peritoneal macrophages. Proc Soc Exp Biol Med 1973; 142; 1123-1127.

7 Nielsen F H, Sunde M I, Hoekstra W G. Alleviation of leg abnormality in zinc deficient chiks by histamine and by various anti-arthritic agents. $J$ Nutr $1968 ; 94 ; 527-533$.

8 Henkin R I. Editorial: zinc in wound healing. $N$ Engl J Med 1974; 291; 675-676.

9 Beng B O, Kit Y K, Greaves M W, Plummer V M. (1974). Trophic skin ulceration of leprosy: skin and serum zinc concentration. Br Med J 1974; 2; 531-533.

10 Flynn A, Pories W J, Strain W H, Hill O A Jr. Zinc deficiency with altered adrenocortical function and its relation to delayed healing. Lancet $1973 ; 1 ; 789-790$.

11 McCall J T, Goldstein N P, Randall R V, Gross J B. Comparative metabolism of copper and zinc in patients with Wilson's disease (hepatolenticular degeneration). Am J Med Sci 1967; 254; 13-23.

12 Fell G S. Zinc. Proc Roy Soc Med 1976; 69; 474-476.

13 Halsted J A, Smith C J Jr, Plasma zinc in health and disease. Lancet 1970; 1; 322-324. 
14 Flynn A, Pories W J, Strain W H, Hill O A Jr, Fratiane R B. Rapid serum zinc depletion associated with corticosteroid therapy. Lancet $1971 ; 2 ; 1169-1171$.

$15 \mathrm{Jaffe} J$ A. Penicillamine treatment of rheumatoid arthritis. In: Munthe E, ed: Penicillamine Research in Rheumatoid Disease. Oslo: Fabritius, 1977; 11-24.

16 Simkin P A. Oral zinc sulphate in rheumatoid arthritis. Lancet 1976; 2; 539-542.

17 Fell G S. Zinc in clinical nutrition. Scott Med J 1975; 20; 101-102.

18 Giroux E L, Henkin R I. Competition for zinc among serum albumin and amino acids in human serum. Biochim Biophys Acta 1972; 273; 64-72.

19 Gerber D A. Low free serum histidine concentration in rheumatoid arthritis. A measure of disease activity. $J$ Clin Invest 1975 ; 55; 1164-1173.

20 Hannson L, Hunnan-Seppala A, Mattila A. The content of calcium, magnesium, copper, zinc, lead and chromium in the blood of patients with rheumatoid arthritis. Scand $J$ Rheumatol 1975; 4; 33-38.

21 Aeseth J, Munthe E, Forre O, Steinnes E. Trace elements in serum and urine of patients with rheumatoid arthritis. Scand J Rheumatol 1978; 7; 237-240.

22 Plantin L O, Strandberg P O. Whole blood concentrations of copper and zinc in rheumatoid arthritis studied by activation analysis. Acta Rheumatol Scand 1965; 11; 30-34.

23 Niedermeier W, Prillaman W W, Griggs J H. The effect of chrysotherapy on the trace metals in patients with rheumatoid arthritis. Arthritis Rheum 1971; 14; 533-537.

24 Ritchie D M, Boyle J A, McInness J M, Jasani M K, Dalakos T G, Grieveson P, Buchanan W W. Clinical studies with an articular index for the assessment of joint tenderness in patients with rheumatoid arthritis. $Q J$ Med 1968; 37; 393-408.

25 Kennedy A C, Bessant R G, Davis P, Reynolds P M G. The estimation of whole-body zinc and zinc turnover in rheumatoid and osteoarthritis using zinc tracer. $\mathrm{Br} J$ Nutr 1978; 40; 115-123.

26 Flear C T, Cooke W T, Quinton A. Serum potassium levels as an index of body content. Lancet 1957 ; 1; 458 459.

27 Ropes M W, Bennett G A, Cobb S, Jacox R, Jessar R A. Proposed diagnostic criteria for rheumatoid arthritis. Ann Rheum Dis 1957; 18; 49-53.

28 Peaston R T. Determination of copper and zinc in plasma and urine by atomic absorption spectrophotometry. Med Lab Technol 1973; 30: 249-253.
29 MacSween R N M, Hughes H, Breen C, Kitchen P, Cathcart C, Buchanan W W. A comparative study of some commercially available tests for rheumatoid factor. $J$ Clin Path 1974; 27; 368-371.

30 Kamel H, Teape J, Brown D H, Ottaway J M, Smith W E. The determination of copper in ultrafiltrate by atomic absorption spectrometry using carbon furnace atomisation. Analyst 1978; 103; 921-927.

31 Vikbladh I. Studies on zinc in blood. Scand J Clin Lab Invest $1951 ; 3 ; 1-74$.

32 Dick W C. Drug treatment of rheumatoid arthritis. In: Scott J T, ed. Copeman's Textbook of the Rheumatic Diseases. London: Churchill Livingstone, 1978; 404-446.

33 Sigler J W, Bluhm G B, Duncan H, Sharp J T, Ensign D C, McCrum W R. Gold salts in the treatment of rheumatoid arthritis. Ann Intern Med 1974; 80; 21-26.

34 El-Ghobarey A F, Mavirkakis M, MacLeod M, Reynolds P M G, Capell H A, Spencer D G, Balint G, Mathieu J P, McAllister T, Cooney A, Dick W C. Clinical and laboratory studies of levamisole in patients with rheumatoid arthritis. $Q J$ Med. $1978 ; 187 ; 385-400$.

35 McConkey B, Crockson R A, Crockson A P, Wilkinson A R. Effects of some anti-inflammatory drugs: on the acute phase protein in rheumatoid arthritis. $Q \mathrm{~J} \mathrm{Med}$ $1973 ; 42 ; 785-791$.

36 Hallman P S, Perrin D D, Watt A E. The computed distribution of copper (II) and zinc (II) ions among seventeen amino acids present in human blood plasma. Biochem J 1971; 121; 549-555.

37 Prasad A S, Oberleas D. Binding of zinc to amino acids and serum proteins in vitro. $J$ Lab Clin Med 1970; 76; 416-425.

38 Pekarek R S, Beisel W R. Characterisation of the endogenous mediator(s) of serum zinc and iron depression during infection and other stresses. Proc Soc Exp Biol Med $1971 ; 138 ; 728-732$.

39 Beisel W R. Trace elements in infectious processes. Med Clin North Am 1976; 60; 831-849.

40 Burch R E, Sullivan J F. Clinical and nutritional aspects of zinc deficiency and excess. Med Clin North Am 1976; 60; 675-685.

41 Powanda M C, Cockerell G L, Pekarek R S. Amino acid and zinc movement in relation to protein synthesis early in inflammation. Am J Physiol 1973; 225; 399-401.

42 Sharma J N, Zeitlin I J, Brooks P M. A novel relationship between plasma kininogen and rheumatoid disease. In: Girond $\mathrm{J}$ P, ed, Future trends in inflammation. Basel: Birkhauser, 1975 ; 148-153. 